\title{
DISTRIBUTION AND VERTICAL STRATIFICATION OF CARBON AND NITROGEN IN SOIL UNDER DIFFERENT MANAGEMENTS IN THE PAMPEAN REGION OF ARGENTINA $^{(1)}$
}

\author{
Carina Rosa Álvarez ${ }^{(2)}$, Alejandro Oscar Costantini ${ }^{(2,3)}$, Alfredo \\ Bono $^{(4)}$, Miguel Ángel Taboada ${ }^{(2,3)}$, Flavio Hernán Gutiérrez \\ Boem $^{(2)}$, Patricia Lilia Fernández ${ }^{(2)} \&$ Pablo Prystupa ${ }^{(2)}$
}

\section{SUMMARY}

One of the expected benefits of no-tillage systems is a higher rate of soil $\mathrm{C}$ sequestration. However, higher $\mathrm{C}$ retention in soil is not always apparent when notillage is applied, due e.g., to substantial differences in soil type and initial C content. The main purpose of this study was to evaluate the potential of no-tillage management to increase the stock of total organic $C$ in soils of the Pampas region in Argentina. Forty crop fields under no-tillage and conventional tillage systems and seven undisturbed soils were sampled. Total organic $C$, total $N$, their fractions and stratification ratios and the $\mathrm{C}$ storage capacity of the soils under different managements were assessed in samples to a depth of $30 \mathrm{~cm}$, in three layers $(0-5,5-$ 15 and $15-30 \mathrm{~cm})$. The differences between the $C$ pools of the undisturbed and cultivated soils were significant $(p<0.05)$ and most pronounced in the top $(0-$ $5 \mathrm{~cm}$ ) soil layer, with more active $C$ near the soil surface (undisturbed $>$ no-tillage $>$ conventional tillage). Based on the stratification ratio of the labile $\mathrm{C}$ pool (0-5/5$15 \mathrm{~cm}$ ), the untilled were separated from conventionally tilled areas. Much of the variation in potentially mineralizable $C$ was explained by this active $C$ fraction $\left(R^{2}\right.$ $=0.61)$ and by total organic $C\left(R^{2}=0.67\right)$. No-till soils did not accumulate more organic $C$ than conventionally tilled soils in the $0-30 \mathrm{~cm}$ layer, but there was substantial stratification of total and active $C$ pools at no till sites. If the $C$ stratification ratio is really an indicator of soil quality, then the $\mathrm{C}$ storage potential of no-tillage would be greater than in conventional tillage, at least in the surface layers. Particulate organic $\mathrm{C}$ and potentially mineralizable $\mathrm{C}$ may be useful to evaluate variations in topsoil organic matter.

Index terms: no-tillage, soil organic matter fractions, tillage systems, carbon stratification, $\mathrm{C}$ and $\mathrm{N}$ stocks.

\footnotetext{
(1) Received for publication in February 3, 2011 and approved in September 27, 2011.

(2) Professor School of Agronomy, UBA, Av. San Martín 4453, Buenos Aires, 011-4524-8079. E-mail: alvarezc@agro.uba.ar

(3) Research. Soil Instituto. CIRN. INTA Castelar. Las Cabañas y De los Reseros. Castelar - Hurlingham. E-mail: acostantini@cnia.inta.gov.ar

(4) Research. EEA INTA Anguil. Ruta 5 km 580. (6326) Anguil, La Pampa. E-mail: abono@anguil.inta.gov.ar
} 


\title{
RESUMO: DISTRIBUIÇÃO E ESTRATIFICAÇÃO VERTICAL DO CARBONO E NITROGÊEIO EM SOLOS SOB DIFERENTES MANEJOS NA REGIÃO DO PAMPA ARGENTINO
}

\begin{abstract}
Um dos benefícios esperados do uso do plantio direto é um maior sequestro de C. Contudo, nem sempre se observa maior retenção de C no solo quando esse sistema de preparo é utilizado, devido principalmente às diferenças em tipo de solo e conteúdo inicial de C, entre outras. $O$ objetivo deste trabalho foi avaliar o potencial do plantio direto para estocar $C$ orgânico nos solos da Região do Pampa Argentino. Foram coletadas amostras de solo em 40 áreas sob plantio direto ou preparo convencional e em sete campos não cultivados por vários anos. Determinaram-se o C orgânico total, $N$ total, suas frações lábeis, sua taxa de estratificação e a capacidade de estocar $C$ dos solos sob diferentes manejos, na camada de 0-30 cm de profundidade, a qual foi dividida, para fins de amostragem, em três profundidades (0-5, 515 e 15-30 cm). Verificou-se diferença significativa $(p<0,05)$ para todos os pools de Centre os solos não cultivados es cultivados. A diferença mais pronunciada foi verificada na camada superficial ( $0-5 \mathrm{~cm})$, sendo determinado o maior teor de C lábil próximo da superfície do solo (não perturbado > plantio direto > preparo convencional). A taxa de estratificação do $C$ lábil (0-5/5-15 cm) permitiu separar as áreas sob plantio direto daquelas sob preparo convencional. Boa parte da variação em $C$ potencialmente mineralizável foi explicada pela fração lábil do $C\left(R^{2}=0,61\right)$, assim como pelo $C$ orgânico total $\left(R^{2}=0,67\right)$. Os solos sob plantio direto não estocaram mais $C$ orgânico do que os preparados de maneira convencional, na camada de 0 $30 \mathrm{~cm}$. Entretanto, houve substancial estratificação dos pools de C lábil nos locais sob plantio direto, indicando que, se a taxa de estratificação for realmente um indicador de qualidade de solos, as áreas sob plantio direto poderiam ter maior potencial de acúmulo de $C$, pelo menos nas camadas superficiais de solo, se comparada com as áreas sob preparo convencional. $O C$ orgânico particulado e o $C$ potencialmente mineralizável podem ser utilizados para avaliar variações na matéria orgânica da camada superficial do solo.
\end{abstract}

Termos de indexação: sistema plantio direto, frações da matéria orgânica do solo, sistemas de preparo, estratificação do carbono, estoque de $C$ e $N$.

\section{INTRODUCTION}

Temperate agricultural regions across the globe are under increasing pressure to maintain, if not raise, production levels in order to meet the rising food demand (Watson \& Zakri, 2005). One of the most productive areas is the Rolling Pampas region of Argentina (about 4.6 Mha), where cereal and oil crop production has increased three-fold in the last two decades, at the expense of pasture for cattle production (Satorre, 2005). Intensive agricultural production can adversely affect soil quality, as shown by decreasing total and active organic $\mathrm{C}$ levels (Echeverria et al., 1993; Casanovas et al., 1995; Costantini et al., 1996; Diaz Zorita, 1999). The recognition that crop production under intensive tilling can promote soil degradation and raise fuel costs, decreasing net profit, has led to the implementation of no-tillage (NT) systems on about 95 Mha around the world (Lal et al., 2007), including 14 Mha in Argentina (Satorre, 2005). One of the expected benefits for soil under NT is a higher soil $\mathrm{C}$ sequestration (Lal et al., 2007). However, higher $\mathrm{C}$ retention in soil is not always apparent when NT is applied, due mainly to substantial differences in climatic conditions, soil type, initial $\mathrm{C}$ content and crop rotation patterns (Steinbach $\&$ Alvarez, 2006). Much of the cultivated area of the Pampas was converted to NT management after decades of conventional tillage, during which at least half of the original total soil organic C (TOC) was lost (Soriano et al., 1991; Senigagliesi \& Ferrari, 1993). Despite the known advantages of NT farming, few data are available on the TOC recovery potential of NT farmland in the Pampas with a long-term history of conventional tillage.

The erratic response of soils to NT management could be ascribed to the characteristics of TOC, which does not respond as readily to alterations in tillage management as other more active $\mathrm{C}$ pools with shorter turnover times (Quiroga et al., 2001). This active C pool can be analyzed in different ways, for example by quantifying the in vitro soil respiration, measured as C- $\mathrm{CO}_{2}$ production under controlled temperature and moisture conditions (Álvarez et al., 1995). Another method of quantifying the $\mathrm{C}$ pool is by measuring particulate organic matter in wet-sieved $(53 \mu \mathrm{m}$ opening) aggregates (Quiroga et al., 1996). The C pool determined with this method indicates the initial loss of organic matter when undisturbed, never cropped soils are first taken into agricultural 
production (Cambardella \& Elliott, 1992). Soil organic matter stratified with depth is of the indicators of soil quality (Franzluebbers, 2002). The main goal of the current study was to evaluate the potential of no-tillage management to increase the total organic $\mathrm{C}$ stock and its fractions in soils of the Pampas region of Argentina. It was hypothesized that the active $\mathrm{C}$ pools are more influenced by changes in soil management than the total organic $\mathrm{C}$ pool and that they are clearly stratified with depth.

\section{MATERIALS AND METHODS}

\section{Study area and experimental design}

The mean annual rainfall in the Rolling Pampa of Argentina is $940 \mathrm{~mm}$, concentrated in spring and summer, and the mean annual temperature is $17^{\circ} \mathrm{C}$ (Soriano et al., 1991). The soils, developed over aeolian sediments (loess) and grassland vegetation (Soriano et al., 1991), belong predominantly to the Mollisol Order (US Soil Taxonomy). In the West, the soils have a loamy A and a Bt horizon (i.e. Typic Argiudoll), while in the East they have silty loam and silty clay loam A horizons and a Bt horizon with higher clay content than the western horizons (i.e. Abruptic and Vertic Argiudolls; Salazar Lea Plaza \& Moscatelli, 1989). The soil $\mathrm{pH}$ is slightly acidic (around, $6 \pm 0.2$ ) and base saturation higher than $70 \%$. Forty cropped fields (22 under no-tillage and 18 under conventional tillage) and seven undisturbed locations, of the selected soil types and management systems, were sampled across the region (Figure 1). The surface $(0-30 \mathrm{~cm})$ texture of the studied soils is shown in table 1 . Three management types were compared: conventional tillage (CT, using chisel or disk plow), no-tillage (NT) and undisturbed soils (UD). The undisturbed soils corresponded to enclosed, undisturbed areas around country houses and long-term pastures (> 20 yr old) excluded from grazing or grazed at a very low stocking rate. Vegetation consisted predominantly of perennial grasses.

The selected production farms used similar technologies and procedures in terms of, for example, fertilizer rates and herbicide and pesticide application. On some fields, a 2-year crop sequence of maize/mainmain-season soybean planted, while on others a 3 year rotation of maize/wheat-soybean/main-season soybean or year-round soybean was maintained. Mean fertilizer rates were $50 \mathrm{~kg} \mathrm{ha}^{-1} \mathrm{~N}$ (as urea or urea$\mathrm{NH}_{4} \mathrm{NO}_{3}$ ) and $16 \mathrm{~kg} \mathrm{ha}{ }^{-1}$ of $\mathrm{P}$ (as diammonium or monoammonium phosphate), applied to maize and wheat. Periods of UD and CT management always lasted several decades, while continuous NT periods lasted 5-18 yr. At least four years of continuous NT management is required to improve soil physical conditions in the surface layers (Voorhees \& Lindstrom, 1984; Rhoton, 2000). Under NT, weeds were controlled with herbicides (mainly glyphosate and atrazine) and under CT mechanically and chemically.

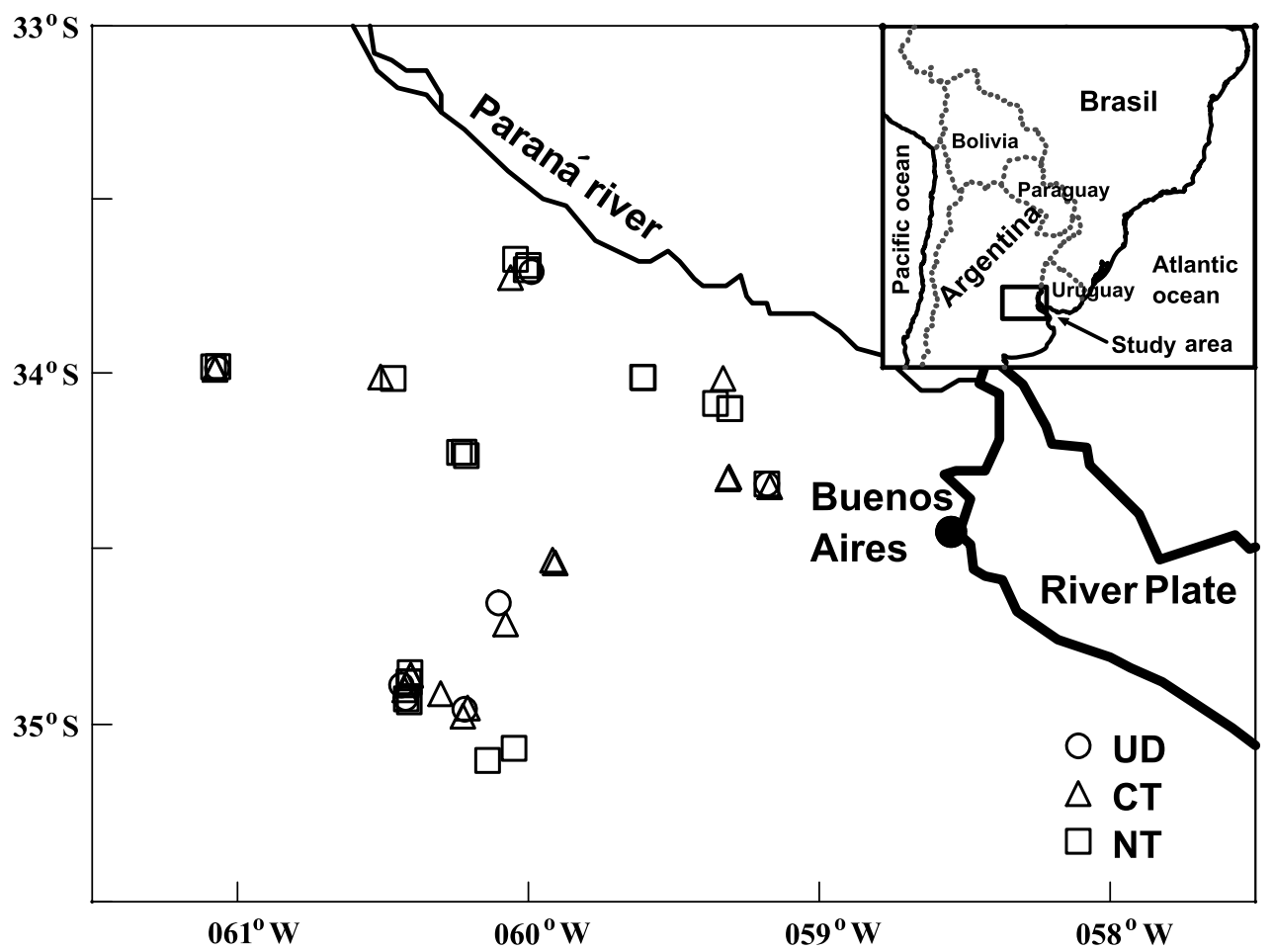

Figure 1. Location of the studied sites. Undisturbed (UD), no tilled (NT) and conventionally tilled (CT) soils. 
Table 1. Clay, silt and sand content of the studied soils of the different texture groups $(0-30 \mathrm{~cm})$

\begin{tabular}{clccc}
\hline $\begin{array}{c}\text { Texture } \\
\text { group }\end{array}$ & & $\begin{array}{c}\text { Silty } \\
\text { loam }\end{array}$ & $\begin{array}{c}\text { Silty clay } \\
\text { loam }\end{array}$ & Loam \\
\cline { 3 - 4 } Clay & Mean & 249 & 276 & 206 \\
& Maximum & 335 & 325 & 252 \\
& Minimum & 200 & 123 & 165 \\
Silt & Mean & 572 & 582 & 460 \\
& Maximum & 620 & 647 & 529 \\
& Minimum & 525 & 505 & 361 \\
Sand & Mean & 179 & 142 & 334 \\
& Maximum & 275 & 370 & 452 \\
& Minimum & 86 & 57 & 231 \\
\hline
\end{tabular}

\section{Analytical determinations}

Soil samples were collected in previously outlined homogeneous areas (2-3 ha) of each field. Composite samples contained at least 30 sub-samples from the $0-5,5-15$ or $15-30 \mathrm{~cm}$ soil layers, collected with an auger. Samples were taken during the fallow period, between May and July. The measurements were performed in this period to ensure soil reconsolidation after tillage under CT. These composite samples were analyzed for TOC by the Walkley and Black method (Nelson \& Sommers, 1982) and total nitrogen (TN) by the Kjeldhal method. Particle size was determined by the pipette method; samples were pre-treated with $\mathrm{HCl}$ and $\mathrm{H}_{2} \mathrm{O}_{2}$ to destroy carbonates and organic matter, respectively. Additionally, soil aggregates in the composite samples were fractionated by wet sieving to determine particulate organic carbon (POC) and particulate organic nitrogen $(\mathrm{PON})$ in the $>53 \mu \mathrm{m}$ aggregate-size fraction (Quiroga et al., 1996; Cambardella \& Elliot, 1992). The resistant organic carbon (ROC) and resistant organic nitrogen (RON) concentrations were calculated as the difference between TOC and POC or TN and PON, respectively. In vitro $\mathrm{C}$ mineralization was measured after $10 \mathrm{~d}$ at $30{ }^{\circ} \mathrm{C}$ and $50 \%$ of water-holding capacity in the layers $0-5$ and $5-15 \mathrm{~cm}$. C- $\mathrm{CO}_{2}$ production was determined by alkali absorption (Álvarez et al., 1995). In this study, C respired in $10 \mathrm{~d}$ was considered representative of the potentially mineralizable C (Franzluebbers et al., 1995). Soil bulk density was determined by the core method (Burke et al., 1986) using $230 \mathrm{~cm}^{3}$ volume cores $(\mathrm{n}=4)$ of the layers $0-5,5-15$ and $15-30 \mathrm{~cm}$.

Stratification ratios (SR) were calculated as the quotient between concentrations in $0-5 \mathrm{~cm}$ and 5 $15 \mathrm{~cm}$ or $0-5 \mathrm{~cm}$ and $15-30 \mathrm{~cm}$ of TOC, TN and their labile pools.

\section{Statistical analysis}

Data were analyzed by ANOVA for each sampling layer. Homogeneity of variance was always tested. The associations between soil properties were evaluated using simple regressions (Neter \& Wasserman, 1974). Principal component (PC) analysis was performed to find the principal gradients in variability among sites. Gradients are linear combinations of the properties TOC, POC, ROC, TON, PON, RON, and PMC, expressed as equivalent mass and their SR 0-5/5-15 cm.

\section{RESULTS}

The organic $\mathrm{C}$ and $\mathrm{N}$ pools were not affected by "soil management x soil texture" interactions (Table 2). The effect of both factors can therefore be analyzed separately. The total quantities of TOC, TN and labile $\mathrm{C}$ and $\mathrm{N}$ pools (per hectare, equivalent soil mass, Neill et al., 1997) in soil were always significantly higher

Table 2. Quantities (stocks) of total organic carbon (TOC), total nitrogen (TN), particulate organic carbon (POC), resistant organic carbon (ROC), particulate organic nitrogen (PON) and resistant organic nitrogen (RON) per unit of area corrected by equivalent mass for the different managements and soil texture groups

\begin{tabular}{|c|c|c|c|c|c|c|}
\hline Soil management & TOC & TN & POC & ROC & PON & RON \\
\hline & \multicolumn{6}{|c|}{$\mathrm{Mg} \mathrm{ha}^{-1}$} \\
\hline UD & $65.64 \mathrm{a}$ & $6.28 \mathrm{a}$ & $18.69 \mathrm{a}$ & $46.95 \mathrm{a}$ & $1.83 \mathrm{a}$ & $4.45 \mathrm{a}$ \\
\hline NT & $52.05 \mathrm{~b}$ & $5.00 \mathrm{~b}$ & $10.39 \mathrm{~b}$ & $41.66 \mathrm{a}$ & $0.92 \mathrm{~b}$ & $4.08 \mathrm{ab}$ \\
\hline $\mathrm{CT}$ & $54.54 \mathrm{~b}$ & $4.82 \mathrm{~b}$ & $10.71 \mathrm{~b}$ & $43.83 \mathrm{a}$ & $0.92 \mathrm{~b}$ & $3.91 \mathrm{~b}$ \\
\hline $\mathrm{p}$-value & 0.0011 & $<0.0001$ & $<0.0001$ & 0.2560 & $<0.0001$ & 0.0506 \\
\hline \multicolumn{7}{|l|}{ Soil texture } \\
\hline Silty loam & $52.55 \mathrm{a}$ & $4.98 \mathrm{a}$ & $9.37 \mathrm{a}$ & $43.18 \mathrm{a}$ & $0.84 \mathrm{a}$ & $4.14 \mathrm{a}$ \\
\hline Silty clay loam & $55.46 \mathrm{a}$ & $5.08 \mathrm{a}$ & $10.33 \mathrm{a}$ & $45.13 \mathrm{a}$ & $0.99 \mathrm{ab}$ & $4.09 \mathrm{a}$ \\
\hline Loam & $56.77 \mathrm{a}$ & $5.26 \mathrm{a}$ & $14.43 \mathrm{~b}$ & $42.34 \mathrm{a}$ & $1.26 \mathrm{~b}$ & $4.00 \mathrm{a}$ \\
\hline $\mathrm{p}$-value & 0.3169 & 0.7849 & 0.0012 & 0.9150 & 0.0019 & 0.4159 \\
\hline \multicolumn{7}{|c|}{ Management $\mathrm{x}$ soil texture } \\
\hline p-value & 0.7347 & 0.4254 & 0.7070 & 0.4907 & 0.4221 & 0.5331 \\
\hline
\end{tabular}

UD (undisturbed soil), NT (no tillage), CT (conventional tillage). Different letters in the same column indicate significant differences for management systems and soil texture (Tukey test, $\mathrm{p}<0.05$ ). 
in UD than in agricultural soils. NT and CT soils were not significantly different (Table 2).

The cumulative concentrations of the $\mathrm{C}$ and $\mathrm{N}$ fractions are shown by figure $2 a, b$. In the $0-5 \mathrm{~cm}$ and $5-15 \mathrm{~cm}$ layers, both soil TOC and soil TN pools were significantly $(p \leq 0.05)$ higher in UD soils than in both agricultural soils (NT and CT), although differences between UD and the cropped soils were less substantial in $5-15 \mathrm{~cm}$ soil than in the surface layer. TOC concentration did not vary among soil managements in the $15-30 \mathrm{~cm}$ layer, while $\mathrm{TN}$ was significantly lower in NT soils. The active $\mathrm{C}$ fraction (POC) differed significantly among the three management methods in the $0-5 \mathrm{~cm}$ layer (UD $>$ NT $>$ CT) and was significantly higher in UD than in agricultural soils in the 5-15 and 15-30 cm layers. The ROC was also significantly higher in UD in the $0-5$ and $5-15 \mathrm{~cm}$ layers but there were no significant differences in the 15-30 cm layer. Similarly, both N fractions (PON and $\mathrm{RON}$ ) were significantly higher
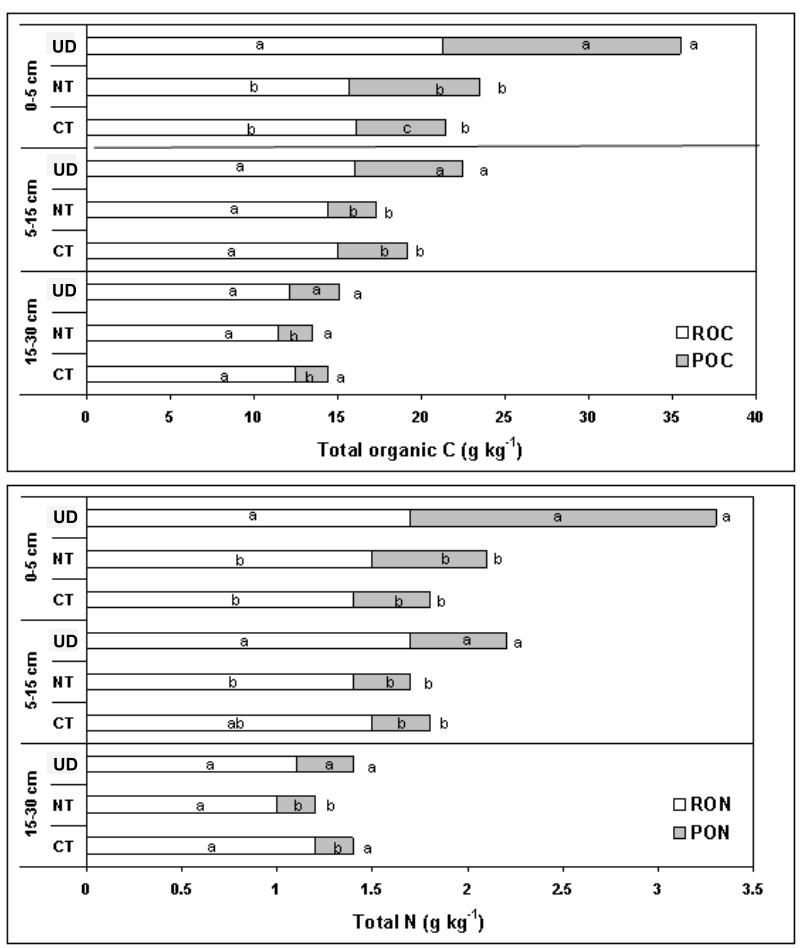

Figure 2. Concentrations of (a) total organic carbon content (TOC) as the sum of particulate organic carbon (POC) and resistance organic carbon (ROC) and (b) total nitrogen (TN) as the sum of particulate organic nitrogen $(\mathrm{PON})$ and resistance organic nitrogen ( $R O N)$ in soil from three different layers and for different management strategies. NT: untilled soils $(n=22)$; CT: conventionally tilled soils $(n=18)$; UD: undisturbed soils $(n=7)$. Different letters indicate statistical differences between management strategies within a soil layer (Tukey test $p<0.05$ ). Each $\mathrm{C}$ and $\mathrm{N}$ component, as well as total $\mathrm{C}$ and $\mathrm{N}$, were analyzed separately. in UD than in the agricultural soils in the $0-5$ and 5$15 \mathrm{~cm}$ layers, but there were no significant differences in the $15-30 \mathrm{~cm}$ layer.

Soil PMC was significantly higher in UD soils than in agricultural soils in the $0-5 \mathrm{~cm}$ (UD $>\mathrm{NT}=\mathrm{CT}$ ) and in the $5-15 \mathrm{~cm}$ (UD $>\mathrm{NT}<\mathrm{CT}$ ) layers (Table 3). More than $60 \%$ of the variation in PMC was explained by either TOC or POC (Figure 3a,b). Although there also seemed to be a positive relationship between PMC and soil ROC, there was considerably more variation in the data, with a coefficient of determination $\left(\mathrm{R}^{2}\right)$ of 0.233 (Figure 3c).

Stratification ratios from the $0-5 \mathrm{~cm}$ to the $5-$ $15 \mathrm{~cm}$ layers ranged from 0.9 to 1.6 when calculated with total and resistant $\mathrm{C}$ and $\mathrm{N}$ pools, such as TOC, TN, ROC and RON (Figure 4a,b). When calculated using labile $\mathrm{C}$ and $\mathrm{N}$ pools such as POC, PMC and PON, SR were higher, with values exceeding 2 (Figure $4 \mathrm{a}, \mathrm{b}$ ). The TOC $0-5 / 5-15 \mathrm{~cm}$ SR differed significantly between soil management strategies (1.59 in UD, 1.36 in NT and 1.13 in CT soils). The same trend was observed for TN. For SR 0-5/15-30 cm, differences between the tillage systems disappeared and the ratios increased in response to substantial decreases of TOC and TN concentration with depth. Values were rarely $>2$ when calculated with total and resistant $\mathrm{C}$ and $\mathrm{N}$ pools and reached 4.7-5.3 when calculated with the labile $\mathrm{C}$ and $\mathrm{N}$ pools (Figure 4c,d).

Table 3. Potential mineralizable carbon (PMC) in different layers of undisturbed (UD), untilled (NT) and conventionally tilled (CT) soils. Statistically different $(p<0.05)$ means are indicated by different letters in the same column

\begin{tabular}{|c|c|c|}
\hline \multirow[t]{2}{*}{ Management } & \multicolumn{2}{|c|}{ PMC $\left(\mu \mathrm{g} \mathrm{C}-\mathrm{CO}_{2} \mathrm{~g}^{-1}\right)$} \\
\hline & $0-5 \mathrm{~cm}$ & $5-15 \mathrm{~cm}$ \\
\hline UD & $457 \mathrm{a}$ & $146 \mathrm{a}$ \\
\hline $\mathrm{NT}$ & $202 \mathrm{~b}$ & $53 \mathrm{c}$ \\
\hline $\mathrm{CT}$ & $177 \mathrm{~b}$ & $83 \mathrm{~b}$ \\
\hline
\end{tabular}

\section{DISCUSSION}

The absence of soil disturbance is critical to maintain $\mathrm{C}$ and $\mathrm{N}$ levels high (Hermle et al., 2008). The studied UD soils partially reflect the theoretical conditions of the Pampas prior to the introduction of agriculture by the end of the $19^{\text {th }}$ century (Soriano et al., 1991). Long-term agriculture during most of the $20^{\text {th }}$ century caused a significant decrease in TOC and TN stocks, as evidenced by the data of the cropped soils (Table 2). Differences in $\mathrm{C}$ and $\mathrm{N}$ levels between UD and the cropped soils were highest in the surface soil layers and essentially absent in the lowest 15- 

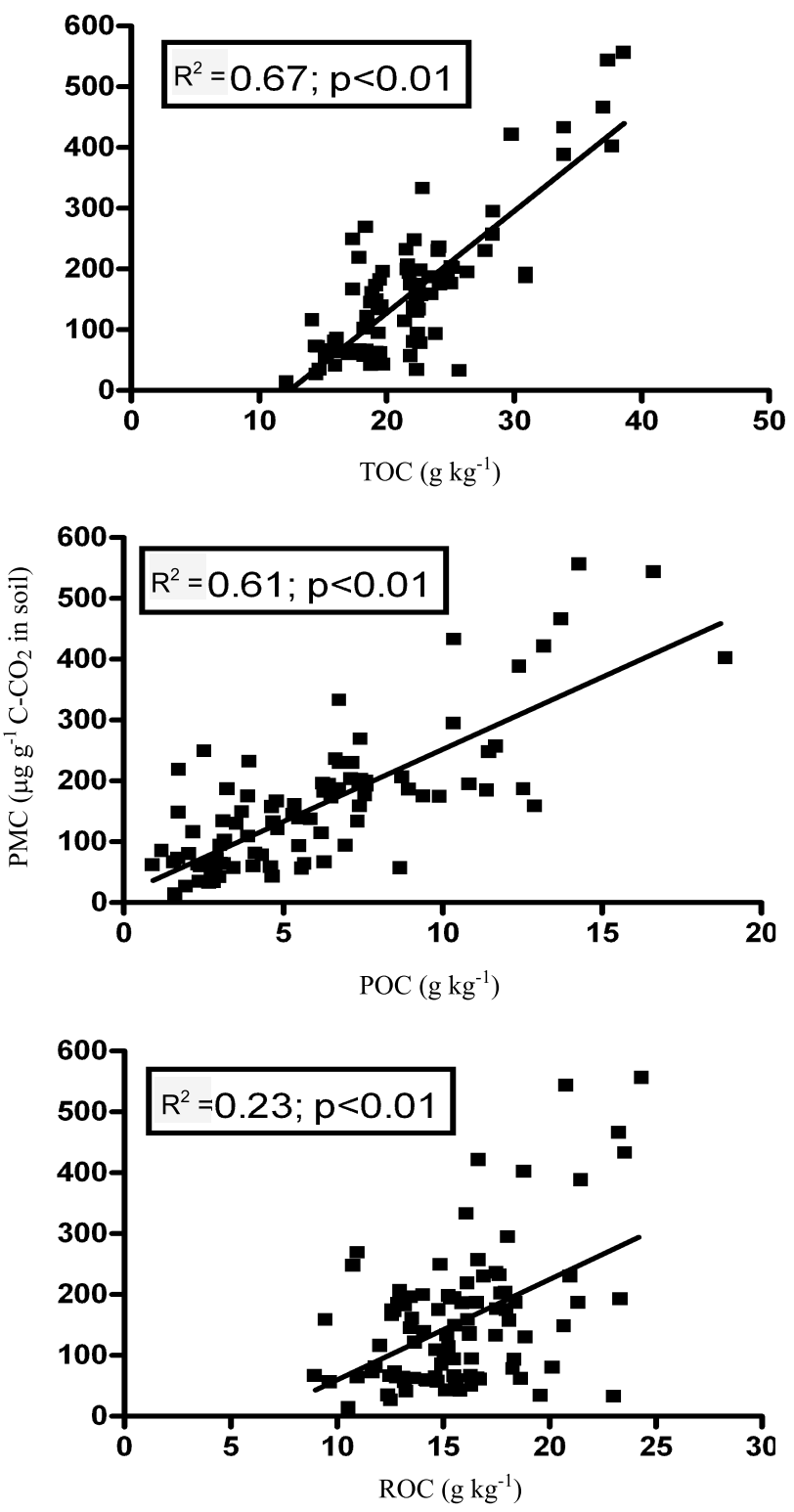

Figure 3. Relationship between potentially mineralizable carbon in $10 \mathrm{~d}$ (PMC) and (a) total carbon content (TOC), (b) particulate organic carbon (POC) and (c) resistant organic carbon (ROC).

$30 \mathrm{~cm}$ layers. This pattern is consistent with similar temperate soils (Dalal \& Mayer, 1986).

Repeated tillage and surface traffic alter the nature of the soil, causing compression and compaction. Reducing tillage and the associated vehicular traffic would expectedly cause differences in soil bulk density. Therefore, soil TOC and TN stocks were calculated to a depth of $30 \mathrm{~cm}$, according to recommendations of Sisti et al. (2004). TOC in UD soils was significantly higher than in CT and NT soils, with no differences between the latter two (Table 2). A decrease of around $23 \%$ in TOC was observed as a consequence of agricultural activity. Hermle et al.
(2008) found similar C stocks at depths down to $40 \mathrm{~cm}$ under different tillage systems; only pasture had higher $\mathrm{C}$ stocks than agricultural soils. D’Haene et al. (2009) reported no differences in $\mathrm{C}$ sequestration under different tillage methods for the $0-0.6 \mathrm{~m}$ layer in Belgium, which represents a colder climate than the Rolling Pampa of Argentina.

It was hypothesized that after some years of continuous NT, organic $\mathrm{C}$ in soils could recover, slowly rising to pre-tillage levels. In a review of long-term tillage trials in the Pampas, Steinbach \& Alvarez (2006) reported that $\mathrm{C}$ stocks (equivalent soil mass) under no-tillage were $5 \%$ higher than traditionally plowed soil. Since our study included only production fields, variables other than tillage may have affected results, such as the history of a given area prior to the introduction of no-tillage. In addition, in the CT systems studied here chisel and harrow disk tillage were used, the most commonly used tillage systems in the region. Minimized tillage with these techniques, as opposed to moldboard plowing, induces $\mathrm{C}$ sequestration (West \& Post, 2002). However, seemingly contradictory results regarding the impact of tillage method on $\mathrm{C}$ sequestration can be attributed to the form of data processing, specifically, calculation on a concentration or a mass basis (Sisti, 2005). Baker et al. (2007) reported that in studies in which the deeper soil layers were evaluated generally no higher $\mathrm{C}$ sequestration was observed in NT than in CT soils. In fact, TOC may be higher in the deeper layers of CT than NT soils, although this case was not observed in our study.

The accumulation of the labile and resistant $\mathrm{C}$ and $\mathrm{N}$ fractions in the upper layer $(0-5 \mathrm{~cm})$ of UD soils may be due to the higher $\mathrm{C}$ inputs from perennial grasses, the decrease of $\mathrm{C}$ input by roots with depth (Jobbagy \& Jackson, 2000), and the lack of disturbance, compared with cropped soils. In general, when soil is cropped, the organic C content is adversely affected, because the organic matter input is reduced, and the decomposition of soil organic matter is accelerated by tillage (Gupta \& Germida, 1988; Richter et al., 1990).

The amount of labile organic matter is generally higher under conservation tillage systems since residue and organic matter decomposition rises in concert with the amount of tillage? increase according to the degree of tillage disturbance (Richter et al., 1990). Our data showed higher soil POC, an active $C$ pool, in the surface layer of NT compared to CT soils (Figure 2). Because crop residues are not incorporated into the soil in no-tillage systems and due to the absence of mechanical disruption, there is an increase in POC in the top $5 \mathrm{~cm}$ (Alvarez et al., 1998; Fabrizzi et al., 2003; Steinbach \& Alvarez, 2006). Because of this increase and in view of the greater sensitivity of POC compared with TOC or ROC, soil POC could be considered an early indicator of the potential future TOC increase under NT, as well as in other C labile fractions such as microbial biomass $\mathrm{C}$ (Sparling et 
要

(a)

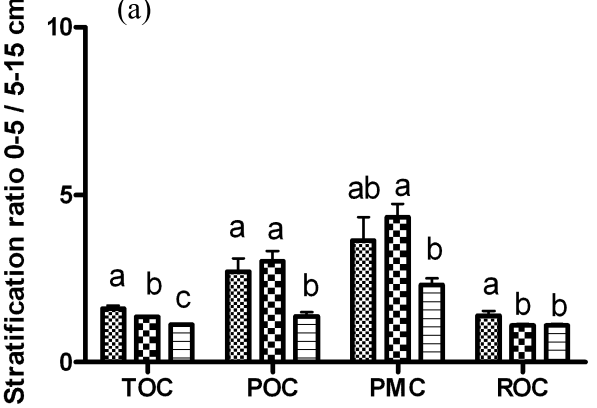

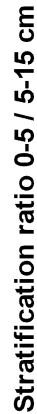

(b)

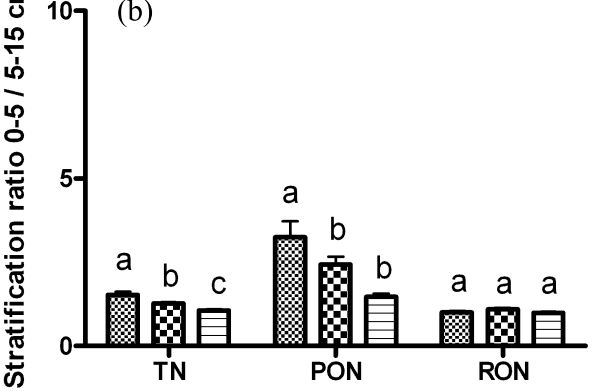

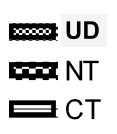
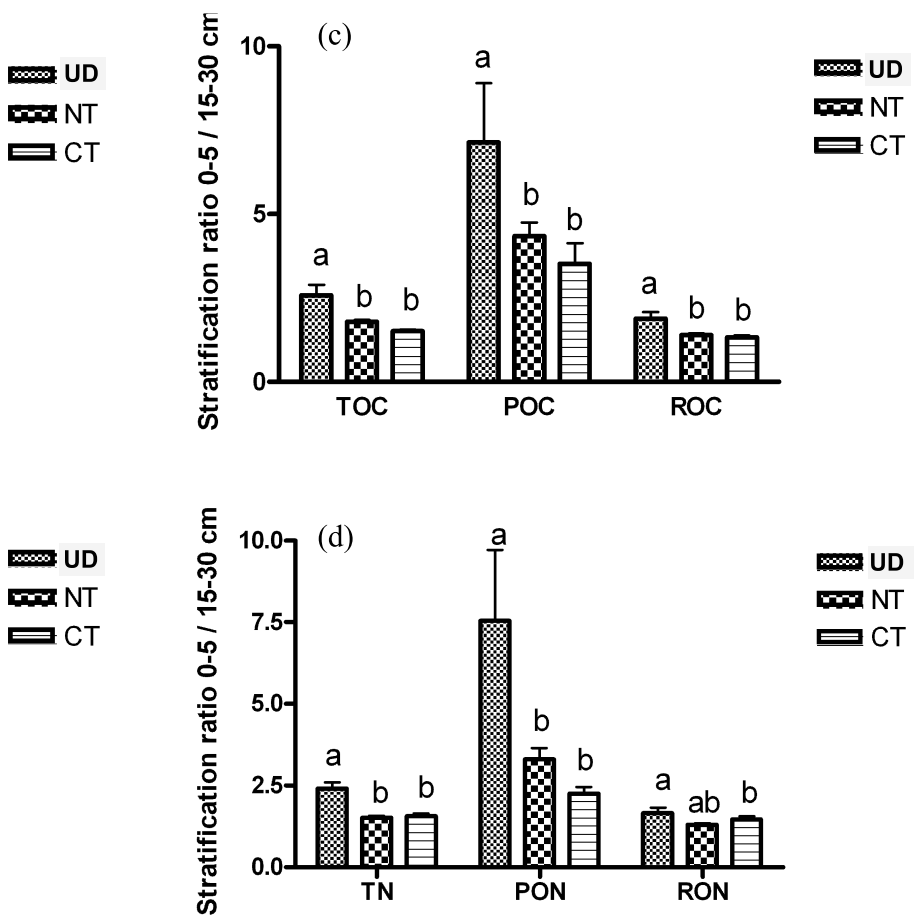

Figure 4. Stratification ratios for the layers $0-5 / 5-15 \mathrm{~cm}$ and $0-5 / 15-30 \mathrm{~cm}$ for (a \& c) total organic carbon (TOC), particulate organic carbon (POC), potential mineralizable carbon (PMC, 0-5/5-15 cm only) and resistant organic carbon $(\mathrm{ROC})$ and $(\mathrm{b} \& \mathrm{~d})$ total nitrogen $(\mathrm{TN})$, particulate organic nitrogen (PON), resistant organic nitrogen $(\mathrm{RON})$. Different letters indicate statistical differences among treatments. NT: untilled soils; CT: conventionally tilled soils; UD: undisturbed soils (Tukey test, $p<0.05$ ).

al., 1992) or potentially mineralizable C (Franzluebbers et al., 1995). In contrast to POC, soil PON, the active nitrogen pool, was not enriched in the surface soil layer under NT.

The TOC and TN concentrations in NT and CT soils were similar in the top $5 \mathrm{~cm}$ (Figure 2), in contrast to some other studies which have reported that TOC and TN concentrations were higher in NT than in CT soils (Franzluebbers, 2002; Hermle et al., 2008), but in agreement with another study developed in the Argentine Pampas, in a 10 year experiment sampled at three depths (Costantini et al., 2006). The proportion of POC in TOC was higher in the surface of NT and UD than of CT soils, a trend that correlated with the lack of soil mechanical disturbance (Alvarez et al., 1998; Fabrizzi et al., 2003; Steinbach \& Alvarez, 2006).

There were some differences in soil ROC and RON pools among the management strategies (Figure 2). In UD soils, more ROC and RON was found in the 0 $5 \mathrm{~cm}$ layer than at the agricultural sites. Hermle et al. (2008) also observed this trend for the ROC fraction. The differences among management strategies they reported were not as pronounced as ours, but their study considered the $0-10 \mathrm{~cm}$ layer. The soil management strategy did not affect soil ROC below $5 \mathrm{~cm}$.

Soil PMC was also significantly higher in UD than in agricultural soils. Within this group, soil PMC was similar in CT and NT soils in the $0-5 \mathrm{~cm}$ layer but was significantly higher in $\mathrm{CT}$, relative to NT, in the $5-15 \mathrm{~cm}$ layer. Similar results were found by Costantini et al. (2006) for soils of the humid Pampean region of Argentina. Costantini, (2003) also reported higher TOC and PMC values in uncropped than in agricultural soils, regardless of the tillage system in use. Much of the variation in soil PMC was explained by TOC and POC concentration (Figure 3). Alvarez \& Alvarez (2000) detected a close relationship between mineralized $\mathrm{C}$ and the light $\mathrm{C}$ fraction (density $<1.6 \mathrm{~g} \mathrm{~cm}^{-3}$ ) and TOC. Several studies have suggested that the physical fractionation of the $\mathrm{C}$ components is useful to assess short-term changes in soil conditions induced by modifications of the management strategies (Alvarez \& Alvarez, 2000). Mc Lauchalan \& Hobbie (2004) found a high correlation between the light $\mathrm{C}$ fraction $\left(<1.7 \mathrm{~g} \mathrm{~cm}^{-3}\right)$, hydrolysable $\mathrm{C}$, soil microbial biomass, $12 \mathrm{~d}$ respired $\mathrm{C}$ and the labile $\mathrm{C}$ pool. According to the correlation found between POC and PMC (Figure 3), soil POC can be considered a good indicator of the C-labile pool.

Stratification ratios varied between the three soil management methods (Figure 4). Stratification was always highest in UD soils, which can be considered the most representative of the original, pre-agriculture soil conditions. Stratification was generally lowest in CT soils, in which tillage homogenized the soil components, leading to a more even distribution of $\mathrm{C}$ 
and N. Other studies reported similar trends (Franzluebbers, 2002). Stratification was expected to increase in NT soils where crop residues are not mechanically incorporated into the soil. Franzluebbers (2002) proposed using the stratification rate as a soil quality indictor. Sá \& Lal (2009) found a close relationship between the stratification rate and soil organic C stock. In our study, stratification ratios in NT were only significantly higher than in CT soils when calculated from the $0-5$ to the $5-15 \mathrm{~cm}$ layers. Some variables (i.e. ROC, RON and PON) showed no differences between CT and NT soils, while others (i.e. TOC, POC and PMC) seemed to recover under NT management, returning to the high stratification ratio characteristic of UD soils. The degree to which stratification increased in UD soils was higher for soil POC and PMC, indicating these $\mathrm{C}$ pools as the most suitable parameters for assessments of variations in topsoil organic matter quality. This increase in stratification is noteworthy, since major differences are generally identified in soils of warm, humid climates with low TOC content (Franzluebbers, 2002); these conditions were however not observed in the studied areas. The magnitude of the stratification patterns identified in our study was similar to results reported by Sá \& Lal (2009).

The principal component (PC) analysis for organic $\mathrm{C}$ and nitrogen stocks (TOC; POC; ROC; TN; PON; RON and PMC) and their SR 0-5/5-15 cm (Figure 5) showed that $50 \%$ of the variance was explained by the first two axes and $33 \%$ by the first axis. Soil total organic pools (TOC and TN) and the labile pools (PCM, POC and PON) were positively weighted. This

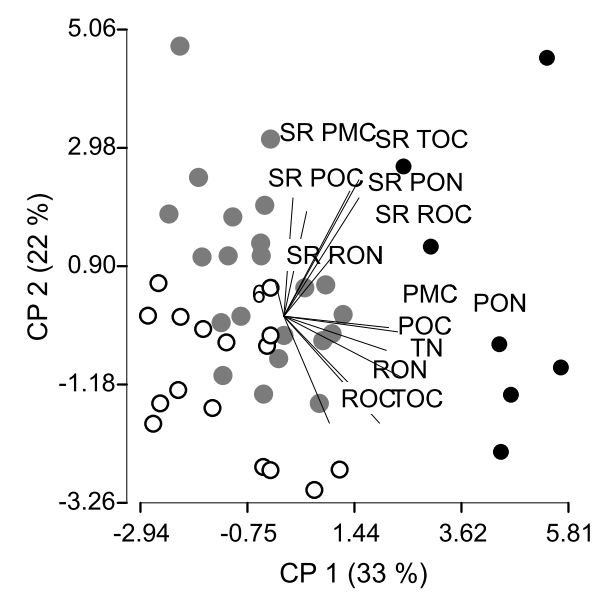

Figure 5. Biplot of principal component analysis. Vectors indicate the relative weight of each variable on the axes: total organic carbon (TOC) and nitrogen (TN), particulate organic carbon (POC) and nitrogen (PON), potential mineralizable carbon (PMC), resistant organic carbon (ROC) and nitrogen (RON), and their stratification ratios (SR) 0-5/5-15 cm. Shaded circles: no-tillage soil (NT), empty circles: conventionally tilled soil (CT); and black circles: undisturbed soil (UD). first PC axis clearly distinguished UD from agricultural sites (CT and NT). This result is in agreement with the ANOVA analysis. The second $\mathrm{PC}$ axis explained $22 \%$ of variance. The main components of this axis were the SR of TOC, TN and their fractions. This second PC axis distinguished NT from CT sites.

\section{CONCLUSIONS}

Continuous NT management indicated no recovery of TOC in the Pampas of Argentina. However, there was a substantial stratification of active organic $\mathrm{C}$ pools at the NT sites, mainly when the stratification ratio was based on the two surface layers, indicating POC and PMC as useful properties for assessments of variations in topsoil organic matter quality. Much of the variation in soil PMC was explained by POC, so this latter fraction can be considered a good indicator of the C-labile pool. PC analysis showed that total organic pools and their labile fractions allowed a distinction of UD from agricultural sites, while SR were higher in NT than in CT.

\section{ACKNOWLEDGEMENTS}

We thank the "Agencia Nacional de Promoción Científica y Tecnológica" (ANPCyT), for the scholarships of the Fondo para la Investigación Científica y Tecnológica (FONCyT), and the University of Buenos Aires (G 403) for funding our research during the preparation of this paper.

\section{LITERATURE CITED}

ALVAREZ, R. \& ALVAREZ, C.R. Soil organic matter pools and their associations with carbon mineralization kinetics. Soil Sci. Soc. Am. J., 64:184-189, 2000.

ÁLVAREZ, R.; DÍAZ, R.; BARBERO, N.; SANTANATOGLIA, O. \& BLOTTA, L. Soil organic carbon, microbial biomass and $\mathrm{C}-\mathrm{CO}_{2}$ production from three tillage systems. Soil Tillage Res., 33:17-28, 1995.

ÁLVAREZ, C.R.; ÁLVAREZ, R.; GRIGERA, M.S. \& LAVADO R.S. Associations between organic matter fractions and the active soil microbial biomass. Soil Biol. Biochem., 30:767-773, 1998.

BAKER, J.; OCHSNER, T.; VENTEREA, R. \& GRIFFIS, T. Tillage and soil carbon sequestration - what do we really know? Agric. Ecosyst. Environ., 118:1-5, 2007.

BURKE, W.; GABRIELS, D. \& BOUMA, J., eds. Soil structure assessment. Rotterdam, A.A. Balkema, 1986. 
CAMBARDELLA, C.A. \& ELLIOT, E.T. Particulate soil organic matter changes across a grassland cultivation sequence. Soil Sci. Soc. Am. J., 56:777-783, 1992.

CASANOVAS, E.M.; STUDDERT, G.A. \& ECHEVERRIA, H.E. Materia orgánica del suelo bajo rotaciones de cultivos. II Efecto de los ciclos de agricultura y pastura. Ci. Suelo, 13:21-27, 1995.

COSTANTINI, A.; COSENTINO, D. \& SEGAT, A. Influence of tillage systems on biological properties of a Typic Argiudoll soil under continuous maize in central Argentina. Soil Tillage Res., 38:265-271, 1996.

COSTANTINI, A. Estoque de carbono em um Sistema Agrícola do Pampa Argentino. Seropédica, Universidade Federal Rural do Rio de Janeiro, 2003. 66p. (Tese de Doutorado)

COSTANTINI, A.; DE-POLLI H. GALARZA, C.; PEREYRA ROSSIELLO, R. \& ROMANIUK, R. Total and mineralizable soil carbon as affected by tillage in the Argentinean Pampas. Soil Tillage Res., 88:274-278, 2006.

DALAL, R.C. \& MAYER, R.J. Long-term trends in fertility of soils under continuous cultivation and cereal cropping in Southern Queensland. II Total organic carbon and its rate of loss from soil profile. Austr. J. Soil Res., 24:281$292,1986$.

D’HAENE, K.; SLEUTEL, S.; DE NEVE, S.; GABRIELS, D. \& HOFMAN, G. The effect of reduced tillage agriculture on carbon dynamics in silt loam soils. Nutr. Cycl. Agroecosyst., 84: 249-265, 2009.

DIAZ ZORITA, M. Efectos de seis años de labranzas en un Hapludol del noroeste de Buenos Aires, Argentina. Ci. Suelo, 17:31-36, 1999

ECHEVERRIA, H.; BERGONZI, R. \& FERRARI, J. Carbono y nitrógeno de la biomasa microbial de suelos del sudeste bonaerense. Ci. Suelo, 10/11:36-41, 1993.

FABRIZZI, K.P.; MORÓN, A. \& GARCÍA, F.O. Soil carbon and nitrogen organic fractions in degraded vs. nondegraded Mollisols in Argentina. Soil Sci. Soc. Am. J., 67:1831-1841, 2003

FRANZLUEBBERS, A. Soil organic matter stratification ratio as an indicator of soil quality. Soil Tillage Res., 66:95-106, 2002 .

FRANZLUEBBERS, A.; HONS, F.M. \& ZUBERER, D.A. Soil organic carbon, microbial biomass and mineralizable carbon and nitrogen in sorghum. Soil Sci. Soc. Am. J., 59:460-466, 1995.

GUPTA, V.V.S.R. \& GERMIDA, J.J. Distribution of microbial biomass and its activity in different soil aggregate size classes as affected by cultivation. Soil Biol. Biochem., 20:777-786, 1988.

HERMLE, S.; ANKEN, T.; LEIFELD, J. \& WEISSKOPF, P. The effect of the tillage system on soil organic carbon content under moist, cold-temperate conditions. Soil Tillage Res., 98:94-105, 2008.

JOBBÁGY, E. \& JACKSON, R.B. The vertical distribution of soil organic carbon and its relation to climate and vegetation. Ecol. Appl., 10:423-436, 2000.
LAL, R.; REICOSKY, D.C. \& HANSON, J.D. Evolution of the plow over 10,000 years and the rationale for no-till farming. Soil Tillage Res., 93:1-12, 2007.

MCLAUCHLAN, K. \& HOBBIE, S. Comparison of labile soil organic matter fractionation techniques. Soil Sci. Soc. Am. J., 68:1616-1625, 2004.

NEILL, C.; MELILLO, J.; STEUDLER, P.A.; CERRI, C.C.; MORAES, J.F.L.; PICCOLO, M.C. \& BRITO, M. Soil carbon and nitrogen stocks following forest clearing for pasture in southwestern Brazilian Amazon. Ecol. Appl., 7:1216-1225, 1997.

NELSON, D.W. \& SOMMERS, L.E. Total carbon, organic carbon and organic matter. In: PAGE, A.L., ed. Methods of soil analysis. Madison, American Society of Agronomy, 1982. Part 2. p.539-579. (Agronomy, 9)

NETER, J. \& WASSERMAN, W. Applied linear statistical models: Regression analysis of variance and experimental design. Irwin, Homewood IL, 1974. 824p.

QUIROGA, A.R.; ORMEÑO, O. \& PEINEMANN, N. Materia orgánica. Un indicador de calidad de suelos relacionado con la productividad de los cultivos. EEA Anguil "Ing. Agr. Guillermo Covas", INTA, 2001. 28p. (Boletín de Divulgación Técnica, 70)

QUIROGA, A.R.; BUSCHIAZZO, D.E. \& PEINEMANN, N. Soil organic matter particle size fraction of the Semi Arid Argentinian Pampas. Soil Sci., 61:104-108, 1996.

RICHTER, D.; BABBAR, L.I.; HUSTON, M.A. \& JAEGER, M. Effects of annual tillage on organic carbon in a fine textured Udalf: The importance of root dynamics to soil carbon storage. Soil Sci., 149:78-83, 1990.

RHOTON, F.E. Influence of time on soil response to no-till practices. Soil Sci. Soc. Am. J., 64:700-709, 2000.

SÁ, J.C.M. \& LAL, R. Stratification ratio of soil organic matter pools as an indicator of carbon sequestration in a tillage chronosequence on a Brazilian Oxisol. Soil Tillage Res., 103:46-56, 2009.

SALAZAR LEA PLAZA, J.C. \& MOSCATELLI, G. Mapa de suelos de la Provincia de Buenos Aires. Escala 1:500000. SAGyP - INTA, Buenos Aires, 1989. 527p.

SATORRE, E. Cambios tecnológicos en la agricultura argentina actual. Ci. Hoy, 15:24-31, 2005.

SENIGAGLIESI, C. \& FERRARI, M. Soil and crop responses to alternative tillage practices. In: BUXTON, D.R.; SHIBLES, R.; FORSBERG, R.A.; BLAD, B.L.; ASAY, K.H.; PAULSEN, G.M. \& WILSON, R.F., ed. International crop science I. Crop. Madison, Science Society of America, 1993. p.27-35.

SISTI, C.; SANTOS, H.; KOHHANN, R.; ALVES, B.; URQUIAGA, S. \& BODDEY, R. Change in carbon and nitrogen stocks in soil after 13 years of conventional or zero tillage in Southern Brazil. Soil Tillage Res., 76:39-58, 2004.

SISTI, C. Estudo de sistemas de uso do solo e rotações de culturas em sistemas agrícolas brasileiros: Dinâmica de nitrogênio e carbono no sistema solo - planta - atmosfera. Seropédica, Universidade Federal Rural do Rio de Janeiro, 2005. 137p. (Tese de Doutorado) 
SORIANO, A.; LEÓN, R.J.C.; SALA, O.E.; LAVADO, R.S.; DEREGIBUS, V.A.; CAUHÉPÉ, M.A.; SCAGLIA, O.A.; VELÁZQUEZ, C.A. \& LEMCOFF, J.H. Rio de la Plata grasslands. In: COUPLAND, R.T. Ecosystems of the world, 8 A. Amsterdam, Elseiver, 1991. p.367-407.

SPARLING, G.P.; SHEPHERD, G. \& KETTLES, H. Changes in soil organic $\mathrm{C}$, microbial $\mathrm{C}$ and aggregate stability under continuous maize and cereal cropping, and after restoration to pasture in soils from the Manawatu region, New Zealand. Soil Tillage Res., 24:225-241, 1992.

STEINBACH, H.S. \& ALVAREZ, R. Changes in soil organic carbon contents and nitrous oxide emissions after introduction of no-till in Pampean Agroecosystems. J. Environ. Qual., 35:3-13, 2006.
VOORHEES, W.B. \& LINDSTROM, M.J. Long-term effects of tillage method on soil tilth independent of wheel traffic compaction. Soil Sci. Soc. Am. J., 48:152-156, 1984.

WATSON, R. \& ZAKRI, A.H. MA Conceptual framework. In: WATSON, R. \& ZAKRI, A.H. Ecosystems and human well-being: Scenarios. Washington DC, Island Press, 2005. v.2. p.22-33.

WEST, T. \& POST, W. Soil organic carbon sequestration rates by tillage and crop rotation: a global data analysis. Soil Sci. Soc. Am. J., 66:1930-1946, 2002. 